\title{
Making Cents: Life Below the Bottom Rung
}

\author{
Caoimhghin Ó Croidheáin
}

A new series of oil paintings examining the daily existence of people making a living in the worst working conditions in the global economy.

"Nations are not communities and never have been. The history of any country, presented as the history of a family, conceals fierce conflicts of interest (sometimes exploding, most often repressed) between conquerors and conquered, masters and slaves, capitalists and workers, dominators and dominated in race and sex. And in such a world of conflict, a world of victims and executioners, it is the job of thinking people, as Albert Camus suggested, not to be on the side of the executioners."

\section{- Howard Zinn A People's History of the United States}
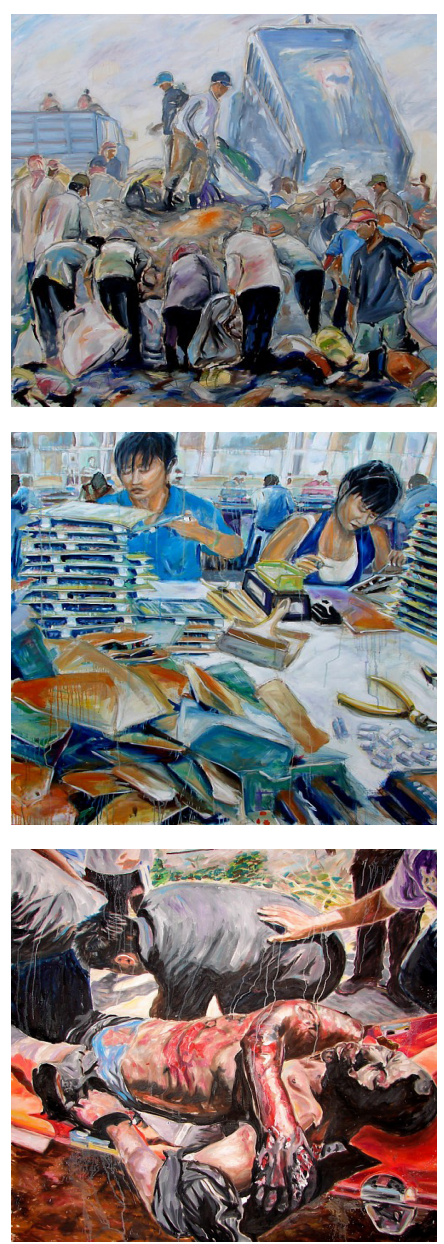
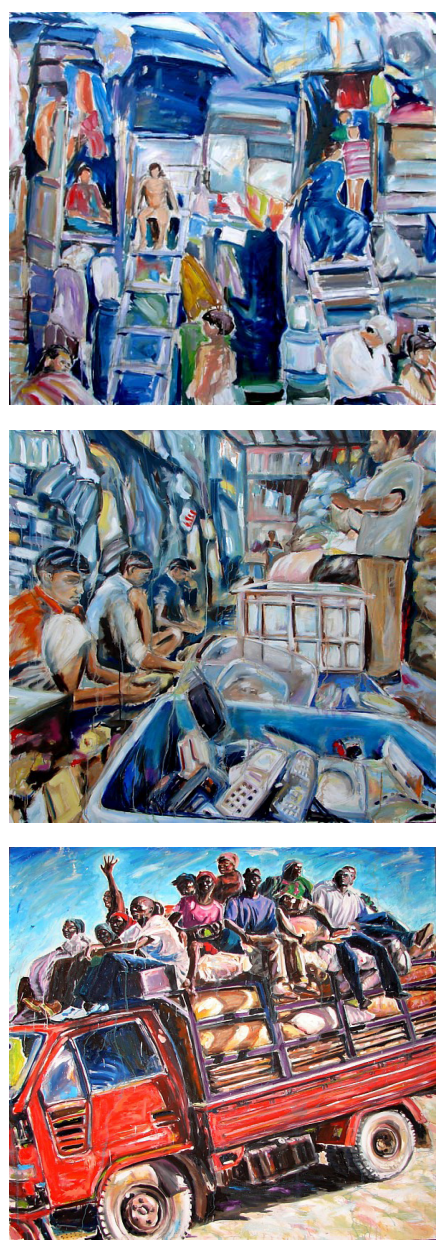
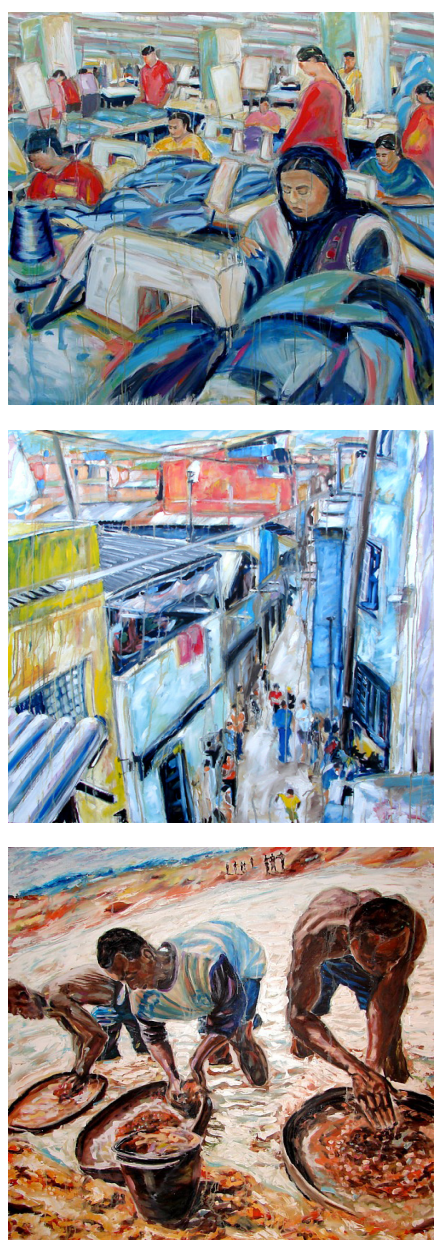

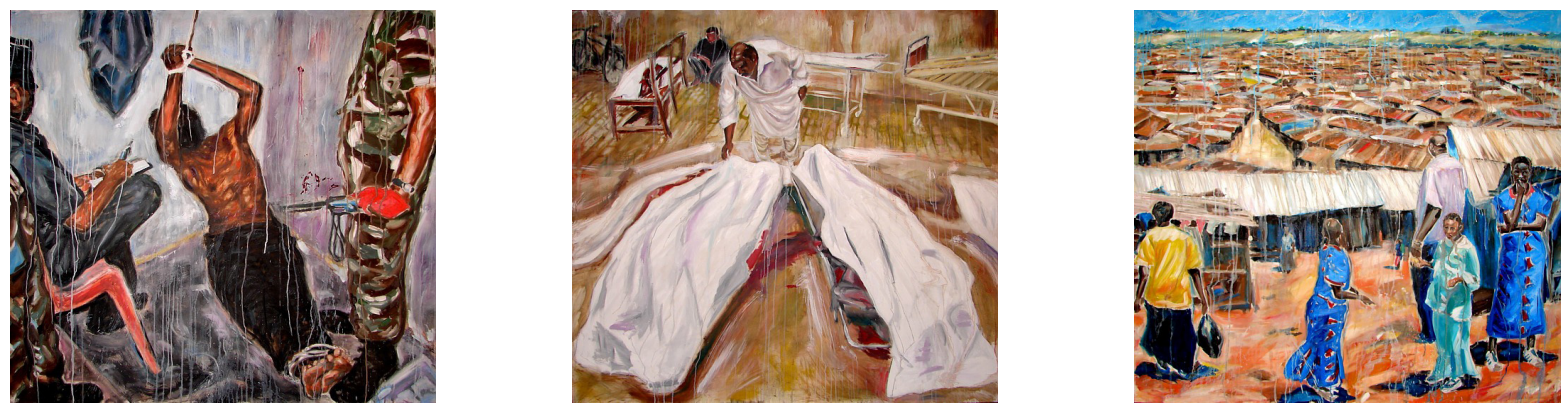

While reading the International Herald Tribune I came across an article entitled 'Deal Near for Global Pact on Ship Recycling' (May 15, 2009). The article notes that ' $\mathrm{t}$ ] he dismantling of ships, so that their steel and other materials can be sold as scrap, is often done on or near beaches in poor countries, notably India and Bangladesh. Both nations have pledged to improve working conditions and environmental practices. But labor advocates contend that the process still kills and maims many workers each year and results in the contamination of shorelines with asbestos, oily waste, toxic paint, and other dangerous materials.' It struck me that it is rare to see images of people in such working conditions depicted in paintings.

Following Sartre's dictum that 'to reveal is to change' I decided to make a painting that would in a sense 'reveal' this type of work to those like myself who had never come across it before. Like many bad situations they continue without change for a long time because of a lack of awareness of their existence by many who often benefit directly or indirectly from them. I looked at other situations where people worked in very bad and sometimes even horrific working conditions (such as recycling in dumps where children have been buried in the process). I talked about this to friends who told me of other situations (such as sulphur workers in Indonesia who carry $70-100 \mathrm{Kg}$ 's on their backs for 2-3hrs to make $\$ 1$ causing at the same time burnt skin and lungs).

The globalization of the world economy has allowed for extremes of exploitation of workers in poor countries. This exploitation is 'hidden' behind advertising and aesthetically designed products. Looking at the people behind the products reminds us that our lifestyle has its negative side too.

An excellent book on this subject is Planet of Slums by Mike Davis published by Verso (2006). 